UNTAG Law Review (ULREV)

Volume 1, Issue 1, May 2017, PP 1-14

ISSN 2549-4910 (online) \& ISSN 2579-5279 (print)

http://jurnal.untagsmg.ac.id/indeks.php/ulrev/indeks

www.fakhukum.untagsmg.ac.id

\title{
PRE-NUPTIAL AGREEMENT AFTER THE ENACTMENT OF DECREE \\ BY CONSTITUTIONAL COURT OF INDONESIA NUMBER: 69 / PUU-XIII / 2015 TO THE THIRD PARTY
}

\author{
Liliana Tedjosaputro \\ Master of Law \\ Universitas 17 Agustus 1945 Semarang
}

\begin{abstract}
Pre-nuptial agreement which was originally provided in Article 119 of the Civil Code and Article 29 of Act Number 1 of 1974 may only be made upon or before the marriage is conducted. As for foreigners who conduct mixed marriage with Indonesian Citizen, without having pre-nuptial agreement before marriage is conducted or upon the marriage is conducted, the joint property in marriage shall be deemed as foreign property and in accordance with the Basic Agrarian Law, land and building which is registered under the name of Indonesian citizen who conduct mixed marriage with foreigners, which is not transferred after one year will become state property. Afterwards the Constitutional Court issued Decree Number : 69/PUU$\mathrm{XIII} / 2015$ which grants permission that pre-nuptial agreement may be made after the marriage is conducted. Can after marriage pre-nuptial agreement be applied retroactively without harming the third party? Pre-nuptial agreement may be made after the marriage is conducted if it's implementation does not harm the third party. Because after the pre-nuptial agreement is made the conjugal property is no longer joint property. The husband and wife property's title shall become their own property title respectively. Thus, Indonesian citizen property shall remain Indonesian citizen property, foreign citizen property shall remain foreign citizen property in mixed marriage. Land which is owned by Indonesian citizen may still be owned by Indonesian citizens because there is no joint ownership of property by foreign citizen.
\end{abstract}

Keywords : Pre-Nuptial Agreement, Third Party, Constitutional Court Decree

\section{INTRODUCTION}

Marriage is basically the institution that binds men and women in a single bond to give and complement each other. The said definition is quite simple but Act Number 1 of 1974 states that the purpose of marriage is to form a happy and lasting family based on God's grace.

According to Prof. R. Subekti marriage is legal bond between a man and a woman for a long time'.

1 Djaja.S.Meliala, (2015), Perkawinan Beda Agama Dan Penghayat Kepercayaan Di Indonesia Pasca Putusan Mahkamah Konstitusi, Bandung : Penerbit Nuansa Aulia, p.22. 
There is often unresolved issues by both parties either husband or wife in a marriage, therefore it requires to be stipulated in the marriage agreement, marriage agreement is often referred to pre-nuptial agreement, and some refers to marriage agreement.

Pre-nuptial agreement was initially known only to the European community and Asiatic Foreigners, which is suitable to their individualistic thoughts and monogamy principle of marriage. This pre-nuptial agreement is able to protect the interests of each party who was often feels unfairly treated in inheritance distribution. Similar to the economy world, they bring a lot of capital into the marriage at the beginning of their marriage, but because their significant other make mistakes in business speculation, their assets are declining even at the end of the marriage they do not gain profit and prosper but they do have debt instead. Then the Civil Code states that as of the date of the marriage, their asset will become joint property, provided there is no agreement otherwise. It is less known in the indigenous communities because it violates to the mutual value.

As the time goes by the pre-nuptial agreement are often utilized by the public, even to the people who adopt Islamic religion, people considers that, although pre-nuptial agreement have bad consequences but the pre-nuptial agreement is quite acceptable as the instrument to prevent assimilation and destruction of the family property, a marriage shall definitely be based on the principle of solidarity and unity between the couple. Each couple will initially promote the common interest, but as the time goes by, personal interest, pre-marriage family interest, and other interests will come. As a result, there would be conflicts and obstacles in the marriage, which often cause issues as unresolved issues in marriage need to be brought to the Religious Court or the District Court for resolution whereas judge's decision usually triggers the issues, which is the same as rulings of other courts where sometimes seems unfair on the side of the husband or wife partner. Usually after the divorce which is followed by distribution of property can cause dissatisfaction, husband or wife's family feel that they has granted both material and other donations in large amount therefore they will also feel at a disadvantage if their property is included into decree which causes transfer of assets into the opposing party. And it is common that wife side is at a loss after the divorce, both physical and material. This often occurs not only on rich family but also on poor family. As a result, although pre-nuptial agreement actually is not welcome at first but it will be a considerabale solution for each family.

Indeed it is not appropriate among the Indonesian people, especially Javanese, who is courteous and hold traditional norms which is inappropriate if there is segregation of assets, as if there is distrust between the couple prior to marriage execution. As if bride and groom has think about divorce before the marriage happen. Pre-nuptial agreement is actually a defensive instrument for each family at the end of marriage.

Actually, if we look closely, pre-nuptial agreement is often used by two society group in Indonesia.

The first group: Indonesian Citizen of Asiatic Foreigners group which are subject to the Civil Code. The first group has obvious reason to use the Pre-nuptial Agreement, namely because they are subject to the Civil Code, which allows to separate property from their spouse.

Pursuant to Article 119 of the Civil Code:

Since the date of the marriage, according to law there happened the community property between husband and wife, provided there is no agreement otherwise. Such community 
property, during the matrimony, cannot be nullified or amended by an agreement between husband and wife.

Therefore they can apply for loan in any credit agreement on behalf of themselves and of course the mortgage does not have collective responsibility, therefore if the debt installment is failed to be paid or default occurs then the spouse of the debtor shall not be responsible for the debt. The pre-nuptial agreement is advantageous because in the calculation of joint property, it will be easily separated between the possessions of husband and wife due to separated property either movable or immovable. Although the underlying principle of pre-nuptial agreement is still traditionally opposed by some parties because of the individualism nature which is still very strong and the pre-nuptial agreement is intended as anticipatory instrument in case of divorce and will protect wife whose interests are often neglected, though judge will usually order husband to provide financial support but the husband will often ignore and not obey judge order. The pre-nuptial agreement shall secure their property and shall not be mixed with husband's property. Besides, it will be clear between husband and wife's property at the time of the separation or the end of a marriage relationship between husband and wife, either because of death or divorce.

The second group : Indonesian citizens who are married to foreigners. The second group is a group of Indonesian citizens who are married to foreigners. After globalization and follow with free trade and MEA, many foreign entrepreneurs visit Indonesia, and they did not only bring capital but also foreign workers, as well as experts in various fields from fields that require special expertise to the field of well-known people such as law, sociology and science. The arrival of foreigners may not only cause issues in their legality of document and other validity which is related to their purpose of visit. Foreigners often mingle with Indonesian, in which their relationship can be in the form of friendship, or other type of relationship like business, and other reason. In Jepara, Central Java, which is mainly known for carved furniture products often found cases where foreigners were having relationship with the Indonesian people to borrow their name to set up a company and obtaining land title in Indonesia. In some cases it does not cause issues because of the short-term nature of their relationship which some refers as contractual marriage. But there are also which may be classified as long-term relationship, where they even record their marriage in Indonesia. After they register their marriage in Indonesia, it will raise legal issues. At the beginning the foreigners were only using the Indonesian people as facilities to have assets, they often procure both land and building assets at the beginning of their marriage to be registered under the name of their wives who are Indonesian citizen. Because their marriage is not legally recorded, the Indonesian people are still legally entitled to and able to control the land and the building as freehold title. But then they record the marriage to the Civil Registry. In such mixed marriages, the state recognizes only one law, and their assets will legally be the state owned land and building. while mixed marriage is a marriage between men and women, each of which are generally subject to the different law².

Article 21 paragraph 3 of Law Number 5 of 1960

(3) Any foreigner, who after the coming into force this Act has obtained the right of ownership through inheritance, without a will or through communal marital property and any Indonesian citizen who have the right of ownership and losing nationality after the

2 Sri Wahyuni. (2016). Hukum Keluarga dan Dinamika Sosial "Kajian Adat Masyarakat Samin, Maluku, Kalimantan dan Sasak, Yogyakarta : Calpulis, p.78. 
coming into force of this law, are obliged to relinquish that right within a period of one year after the obtaining of that right of after losing that nationality. If after expire of that period the right of ownership is not relinquished, then it becomes invalid by the provision that the right of other parties, incumbent hereon, endure.

Article 30 paragraph 2 of Law Number 5 of 1960

(2) Persons or corporations possessing the right of exploitation and who do not any longer meet the terms as mentioned in clause (1) of this Article are obliged within a period of 1 year to relinquish or to transfer that right to another party meeting these terms. This provision is also applicable to a party which has obtained the right of exploitation if his party does not meet the meant terms. If the right of exploitation concerned is not relinquished or transferred within the mentioned period of time, then that right become not valid by the law, with the provision that the rights of the other party shall be observed according of the provision laid down by Government Regulation.

Article 36 paragraph 2 of Law No. 5 of 1960

(2) Person or corporation who posses the right of building and do not any longer meet the requirements mentioned in paragraph (1) of this Article are obliged within a period of one year to relinquish or to transfer that right to another party that meets the requirements. This provision also applies to the party that obtains the right of building, if does not meet the said requirements. If the right of building concerned is not relinquished or transferred in the period as mentioned above the right becomes not valid by law with the provision that right of the other parties shall be transferred, according to the provisions to be laid down by Government Regulation.

These issues may be resolved if there is pre-nuptial agreement before, especially with the issuance of Indonesian Government Regulation Number 103 Year 2015 on Ownership of Dwelling Of Residency House By Foreign Persons Domiciled In Indonesia, whereas Article 3 of the Government Regulation states :

(1) An Indonesian citizen who has married a foreigner has the same rights to the land as other Indonesian citizens.

(2) The rights to the land as referred to in paragraph (1), is not a joint property that is evidenced by the separation agreement of assets between the husband and the wife, which is made by notarial deed.

But although there are changes made, it still caused unrest among Indonesian citizens who has held mixed marriage, they shall still lose their property as they already register marriages at the Civil Registry Office and therefore based on Article 119 of the Civil Code.

And article 29 paragraph 1 of Law No. 1 of 1974

At the time of or prior to the marriage, both parties may by mutual consent conclude an antenuptial contract in writing, legalized by the registrar of marriage, where upon the contents shall also be binding on third parties in so far third parties are effected.

Then Indonesian citizens who are already bound into marriage with foreigner and register then they will lose their title to land and buildings which are already registered under the name of Indonesian citizens. What about their fate, it turns out they were not satisfied to the said facts and then they attempted to change the provisions of pre-nuptial agreement which states pre- 
nuptial agreement may only be done prior to pre-nuptial marriage. Ike Farida an Indonesian citizen attempted to claim this issue which is subject with article 29 of Law No. 1 of 1974 after the Indonesian Constitutional Court grant it as stated in the verdict:

the phrase "at the time or prior the marriage is performed" in Article 29 paragraph (1), the phrase

"by the time of or prior to a marriage" as described under Article 29 (1) of the Marriage Law, the phrase of "...since the marriage takes place" as described under Article 29 (3) of the Marriage Law, and the phrase of "during the span of a marriage" as described under Article 29 (4) of the Marriage Law, limit the freedom of contracting parties as regards the timeframes under which they are allowed to draw up such agreements. Hence, this restriction was viewed as contradicting the various provisions which are set out under Article 28E (2) of the 1945 Constitution, as claimed by the Petitioner.

Which Article $28 \mathrm{E}$ The 1945 Consitution of republic of Indonesia shall be read as follows:

(1) Every person shall be free to choose and to practice the religion of his/her choice, to choose one's education, to choose one's employment, to choose one's citizenship, and to choose one's place of residence within the state territory, to leave it and to subsequently return to it.

(2) Every person shall have the right of freedom to believe his/her faith, and to express his/her views and thoughts, in accordance with his/her conscience.

(3) Every person shall have the right of freedom to associate, to assemble and to express opinions.

Therefore it raises question after the release of the Indonesian Constitutional Court Decree, for both first and second group to third party. Actually, for the second group which are Indonesian citizens who marry foreigners, their objective of claiming article 29 of Law No. 1 of 1974 is that they shall not lose their title as Indonesian citizens to have land and building title thereon. And place as guarantee to Bank. Therefore the impact of this decree for the second group are relatively small, because they are restricted with provisions of pre-nuptial agreement shall be made prior to marriage then they will be refused when applying for loans with collateral that is registered under the name of couple in mixed marriage. It is concluded that the bank are able to settle the issues pursuant to the issuance of the new policy, and it shall not be complicated.

The issues for the first group is very difficult to be settled. They are Indonesian citizens who have rights and recognized by the state, therefore Bank and banking institutions will be delighted to accept loan applications from them, the issues for third parties, if the first group were allowed to make pre-nuptial agreement after the marriage, Bank will find itself at a disadvantage, given the fact that not all Indonesian citizens who are subject to the Civil Code make pre-nuptial agreement, there are some of those who are less aware even they do not know the importance of pre-nuptial agreement, reason for not doing it as it will disrupt the harmony of the family, and the pre-nuptial agreement will also cause husband or wife to manage their own finances, how can they live together with this separation of fund. Because they do not feel the importance, they do not draw pre-nuptial agreement. After the issuance of this decree, they will be able to draw pre-nuptial agreement after marriage. The objective is so that they may avoid their responsibilities as the Borrower and the insured party in the event of default occurs. Many cases occur which the Bank felt disadvantaged because of dishonesty on the Debtor party. For example Debtor is not telling the truth that they are married hence they will be 
acknowledged to the Bank as a single applicant for credit agreement. Then it will cause Debtor to be classified as having made for falsification of data and make the debt of the Borrower is due and shall be paid immediately and simultaneously. The case is different with the prenuptial agreements, as there is no falsification of data, and the decree of the Indonesian Constitutional Court clearly stated that it is the title of each spouse.

For the second group the issues of enforcement of the pre-nuptial agreement is more on the ownership of land and building, before the issuance of the Decree of the Indonesian Constitutional Court, each of land and building which is registered under the name of couple who perform mixed marriage with foreigner without making a pre-nuptial agreement will lose their title if after a period of 1 (one) year it is not transferred to other eligible Indonesian citizen. This is because it has been stipulated in article 21 paragraph 3 of Act Number 5 of 1960 on Basic Agrarian Law provisions, which states:

" Any foreigner, who after the enforcement of this Act has obtained the right of ownership through inheritance without a will or through communal marital property, and any Indonesian citizen who has the right of ownership but after the enforcement of this Act has lost his or her nationality, are obliged to relinquish that right within a period of one year after the obtaining of that right of after losing nationality status. If after the expiry of that period, the right of ownership is not relinquished, then it will belong to the state government however the provision right of other parties, incumbent hereon, endure."

There is legal uncertainty after the implementation of the Indonesian Constitutional Court Decree, how to determine the legal position of assets that is returned to citizen who perform mixed marriage, The lack of clarity is due to the provisions of article 58 of the Marriage Act, namely:

Persons of different citizenship contracting a mixed marriage may obtain the citizenship of the husband/wife and also may lose their own citizenship in accordance with the procedures provided for in the Law on Indonesian Citizenship currently in force.

This means that Article 21 paragraph 3 of the Basic Agrarian Law is intended to protect the assets belonging to Indonesian in order not to be claimed by foreigners where it is in accordance with Nationality principle of the Basic Agrarian Law, namely:

Nationality Principle which contains meaning that the entire territory of Indonesia is God's bless, a unified motherland of the whole of the Indonesian people, whose independence is obtained through the fight of Indonesian people, which become the right of Indonesian people. The stated right is eternal, which means that there is nothing can eliminate the bond between Indonesian people and it's homeland as long as Indonesian people still around. Therefore this principle determines that only Indonesian citizens who may have land title on the basis of property title, regardless of sex men and women, while foreign nationals are prohibited. In order to balance this principle it is also described the mechanism of protection to the citizens, for example by conducting surveillance on any transfer of property title (especially for citizens in a weak economy standing), as well as to maintain the principles of social justice governments are obliged to prevent any organizations or efforts of individuals in the agrarian field which is classified as monopolistic by private citizens. 
The pre-nuptial agreement in general is defined as an agreement which is made by groom and bride to arrange their assets status due to marriage which is deviated from the joint property ${ }^{3}$.

The pre-nuptial agreement is provided in the Indonesian positive law which is adopted in the Civil Code in Article 139, Article 147, Article 148 and Article 149:

Article 139 of Civil Code

The pre-nuptial agreement for the future husband and wife may diverge from the law regulations concerning the community property, provided that such is not contradict with the proper morality or with the public order and the following regulations must also be heed.

\section{Article 147 of Civil Code}

Pre-nuptial agreement must be made with notary deed prior to the marriage, and shall be void if it is not made in such manner.

\section{Article 148 of Civil Code}

Any amendments, which in the first place may be performed prior to the marriage, cannot be performed in other way than in a deed, in the same form as the former agreement deed. Also none of the changes can be enforced without the presence or permission from related party who attend and approve the pre-nuptial agreement.

Article 149 of Civil Code

After the marriage, the pre-nuptial agreement cannot be changed or amended by any manner whatsoever.

Pre-nuptial Agreement in Civil Code is divided into

1. Division of Property (Article 139 of Civil Code)

With the pre-nuptial agreement, bride and groom is entitled to deviate from apllicable laws regarding unification of property, as long as the agreement does not violate the proper morality norms or public order and pursuant to all below rules.

2. Consolidation of Profit and Loss (Article 155 of Civil Code) If the husband and wife to-be only agree that there must be a consolidation of loss and profit then to close this condition to unify the property according to the law, any profit that is obtained by the husband and wife during the matrimony must be divided between them, however the loss must be borne jointly, if the consolidation of community property is discharged.

3. Consolidation of Yields and Income (Article 164 of Civil Code) The agreement, that between the husband and wife only the produce and income that are consolidated, taciturnly shall mean that there is no complete community property in accordance with the law and there shall be no cimmunity loss and profit ${ }^{4}$.

Besides that, the Civil Code also contains restriction on the contents of the pre-nuptial agreement, among others :

1. The pre-nuptial agreement can not contradict with the proper morality or public order (Article 139 of Civil Code)

2. The agreement shall not eliminate or reduce the rights given to the husband as the head of

3 Wahyuni. (2002). Hukum Perdata I Hukum Keluarga, Semarang: Untag- Semarang, p.80.

4 J. Andy Hartanto. (2017). Hukum Harta Kekayaan Perkawinan "Menurut Burgerlijk Wetboek dan UndangUndang Perkawinan", Laksbang Pressindo, Yogyakarta, p.50-58. 
the family. For example, the agreement cannot allow wife to have her own house separate from husband (Article 140 paragraph (1) Civil Code).

3. Pursuant to Article 141 of Civil Code, the husband and wife shall not release the right which is given by the law to inherit their descendants in straight line downward manner (children and grand children)

4. If the joint property is terminated, it should not be contracted. that the husband or wife will pay larger part of the debt than his or her profits in the joint property.

5. They cannot allegedly promise that their marital bond shall be governed by the foreign law or by some traditional customs. (Article 143 of Civil Code) ${ }^{5}$.

From the said description, pre-nuptial agreement was clearly defined by the Civil Code that it may be held at the time before or during the marriage execution, it is strongly related to legal certainty and clarity of the legal position of property between husband and wife, the grounds of the Civil Code that there is possibility of the husband to squander the property in his duty to manage the property. To prevent this possibility, Burgerlijk Wetboek in article 186 of Civil Code grants the possibility to the wife to submit the claim for separation of properties to the judge.

So there are three things that commonly arranged in a Pre-nuptial Agreement, namely:

1. Separate Property

2. Property which is obtained from each business as well as from grants

3. Inheritance or grants which are obtained during the marriage ${ }^{6}$;

Further the Marriage Act Number 1 of 1974 also provides that pre-nuptial agreement may also be made before or at the time of marriage which in article 29 of Act Number 1 of 1974 states:

(1) At the time of or prior to the marriage, both parties may by mutual consent conclude an antenuptial contract in writing, legalized by the registrar of marriage, where upon the contents shall also be binding on third parties who are effected.

(2) The contract cannot be legalized if contrary to the restrictions set by the law, religion or morality.

(3) The contract takes effect from the date of the marriage;

(4) Throughout the continuance of the marriage the contract can not be changed except by mutual agreement between the parties concerning such changes, provided such changes are not prejudicial to the interests of third parties;

From the terms of the pre-nuptial agreement in accordance with the Marriage Act there are some materials that may be concluded:

1. Pre-nuptial agreement is made in writing and legalized by the Registrar of Marriage (Article 29 paragraph 1 of the Marriage Act).

2. Since legalization by the registrar of marriages, its contents of the agreement is binding to the husband and wife and also to the third parties as long the content is related to the third party (article 29 paragraph 2 of the Marriage Act).

3. Pre-nuptial agreement may be registered at the time or before marriage to be legalized by registrar of marriage (article 29 paragraph 1 of the Marriage Act).

4. Pre-nuptial agreement is applied from the date of marriage (Article 29, paragraph 3 of the Marriage Act).

5 Ridhwan Indra. (1994). Hukum Perkawinan di Indonesia, Jakarta : CV. Haji Masagung, p. 101.

6 Abdul Hakim Pradoto Kusumo, "Cermati Bila Menerima Akta Perjanjian Kawin", Renvoi, 3 Maret 2017, 36. 
5. Pre-nuptial agreement cannot be legalized if contrary to the restrictions set by the law, religion or morality. (Article 29, paragraph 2 of the Marriage Act).

6. Throughout the continuance of the marriage the contract can not be changed except by mutual agreement between the parties concerning such changes, provided such changes are not prejudicial to the interests of third parties. (Article 29, paragraph 4 of the Marriage $A c t)^{7}$.

Besides, there are some other important matters, namely:

1. In case of the groom and bride have attained the age of 18 years or married they can make pre-nuptial agreement either before or at the time of marriage.

2. In the event that the bride has reached marriageable age but has not reached the age of 18 years, then it should at least be represented or accompanied by a parent or guardian.

3. In case of the groom and bride married with age dispensation then he/she or they should be represented or accompanied by a parent or guardian ${ }^{8}$.

Pre-nuptial agreement by the Marriage Act look similar but have differences with the Civil Code, namely:

1. Does not require any particular legal form.

2. At the time or before marriage, both parties by mutual consent able to make written agreement approved by the registrar of marriage, thereafter which it shall also be binding on third parties who are effected.

3. The contract cannot be legalized if contrary to the restrictions set by the law, religion or morality.

4. Throughout the continuance of the marriage the contract can not be changed except by mutual agreement between the parties concerning such changes, provided such changes are not prejudicial to the interests of third parties.

5. The agreement is apllicable from the date of marriage.

Marriage Act does not define the pre-nuptial agreement object, for example regarding the property. Because there are no restrictions, it can be concluded that pre-nuptial agreement under the Marriage Act may be described in broadest meaning. In the explanation of Article 29 it is concluded that the concerned agreement doe not include conditional divorce ${ }^{9}$. Both of these provisions emphasize that pre-nuptial agreement may be made before marriage, because they have the same principles that is to protect interests of wife in Indonesian marriage and also in mixed marriage therefore the land belongs to Indonesian people shall not be transferable to foreigner.

Marriage Act provides the opportunity for bride or groom to organize their own property later with very loose flexibility but with restriction that they are not allowed to contradict with the law, morality and religion ${ }^{10}$.

In essence, Pre-nuptial agreement can not be changed during marriage but according to Law Number 1 of 1956 it may be changed if it has been for one year as long as there are reasons husband has acted as beheer instead of bacsking",

7 Wibowo Reksopradoto. (1977). Hukum Perkawinan Nasional, Semarang: Itikad Baik, p. 150.

8 J Satrio. (1991). Hukum Harta Perkawinan, Bandung: Citra Aditya Bakti, p.223.

9 K. Wantjik Saleh. (1976). Hukum Perkawinan Indonesia, Jakarta: Ghalia Indonesia, p.32.

10 Moch. Isnaeni. (2016). Hukum Perkawinan Indonesia, Surabaya : Refika Aditama, p.83.

11 Rosnidar Sembiring. (2016). Hukum Keluarga "Harta Benda dalam Perkawinan", Jakarta : PT Raja Grafindo Persada, p.74. 
From this introduction there is one issue, namely Can after marriage pre-nuptial agreement be applied retroactively without harming the third party?

\section{DISCUSSIONAND ANALYSIS}

On March 21, 2015 decree from The Indonesian Constitutional Court decision was issued which permit pre-nuptial agreement to be made after marriage. It's judicial verdict states as follows:

1. To partially grant the request;

1.1. Article 29 paragraph (1) of Act Number 1 of 1974 on Marriage (State Gazette of the Republic of Indonesia Year 1974 Number 1, Supplement to the State Gazette of the Republic of Indonesia Number 3019) contradicts to the 1945 Constitution of the Republic of Indonesia to the extent it is not defined "By the time of, prior to, or during the span of marriage, both spouses may jointly agree to draw up a written agreement which is registered with the civil registry officer or public notary, after which time the contents of such agreements will also be applicable to other relevant third parties."

1.2. Article 29 paragraph (1) of Act Number 1 of 1974 on Marriage (State Gazette of the Republic of Indonesia Year 1974 Number 1, Supplement to the State Gazette of the Republic of Indonesia Number 3019) is not legally binding to the extent it is not defined "By the time of, prior to, or during the span of marriage, both spouses may jointly agree to draw up a written agreement which is registered with the civil registry officer or public notary, after which time the contents of such agreements will also be applicable to other relevant third parties";

1.3. Article 29 paragraph (3) of Act Number 1 of 1974 on Marriage (State Gazette of the Republic of Indonesia Year 1974 Number 1, Supplement to the State Gazette of the Republic of Indonesia Number 3019) contradicts to the 1945 Constitution of the Republic of Indonesia to the extent it is not defined "Such agreement is immediately applicable from the time of marriage, unless otherwise agreed under the pre-nuptial agreement";

1.4. Article 29 paragraph (3) of Act Number 1 of 1974 on Marriage (State Gazette of the Republic of Indonesia Year 1974 Number 1, Supplement to the State Gazette of the Republic of Indonesia Number 3019) is not legally binding to the extent it is not defined "Such agreement is immediately applicable from the time of marriage, unless otherwise agreed under the pre-nuptial agreement";

1.5. Article 29 paragraph (4) of Act Number 1 of 1974 on Marriage (State Gazette of the Republic of Indonesia Year 1974 Number 1, Supplement to the State Gazette of the Republic of Indonesia Number 3019) contradicts to the 1945 Constitution of the Republic of Indonesia to the extent it is not defined "During marriage, a pre-nuptial agreement may cover marriage assets or other topics and can not be amended or revoked, unless both spouses agree to amend or revoke, and provided that any such amendment or revocation does not harm the interests of any relevant third parties.";

1.6. Article 29 paragraph (4) of Act Number 1 of 1974 on Marriage (State Gazette of the Republic of Indonesia Year 1974 Number 1, Supplement to the State Gazette of the Republic of Indonesia Number 3019) is not legally binding to the extent it is not defined "During marriage, a pre-nuptial agreement may cover marriage assets or other topics and can not be amended or revoked, unless both spouses agree to amend or revoke, and provided that any such amendment or revocation does not harm the interests of any relevant third parties."; 
2. To order the promulgation of this decree in the State Gazette of the Republic of Indonesia;

\section{To reject the petition for the rest/ remainder.}

There are three legal consequences arisen from the Constitutional Court Decision Number: 69/PUU XIII/2015 which changes the form of pre-nuptial agreement which is made after marriage, it is because the time and duration of pre-nuptial agreement which is made after the marriage is different from the pre-nuptial agreement which is made before the marriage.

\section{Pre-nuptial agreement can be made during the marriage}

A married couple, before or at the time of the marriage who intends to make the pre-nuptial agreement, may be made in writing and subsequently registered by the marriage registrar or they may request for Notary to assist in making the pre-nuptial agreement.

\section{The Pre-nuptial Agreement Should Not Harm Third Party}

To protect the interests of third party there should be procedures that must be taken so that third party are given the opportunity to object to pre-nuptial agreement that will be created by the husband and wife during marriage if it will be detrimental to him. If the procedure is not provided in the applicable laws then notary before making the pre-nuptial agreement should ask to the married couple to make promulgation in a newspaper which is distributed in the said city of domicile of the parties, which has a wide circulation and shall be placed on the easily legible page.

When Notary is requested to make pre-nuptial agreement which refers to the Indonesian Constitutional Court decress, they should pay attention to:

1. Request of inventory of assets which is acquired during marriage that will be included in the deed.

2. Statement that the stated assets have not been transacted in the manner of and in any form to anyone ${ }^{12}$.

\section{Enactment of Pre-nuptial agreement During Marriage}

Such agreement is immediately applicable from the time of marriage, unless otherwise agreed under the pre-nuptial agreement. Article 29 of the Marriage Act, which reads "Pre-nuptial agreement is immediately applicable from the time of marriage." Pursuant to the Indonesian Constitutional Court it should be interpreted "Pre-nuptial agreement is immediately applicable from the time of marriage, unless otherwise agreed under the pre-nuptial agreement."

Pursuant to the provisions of the Constitutional Court if the parties do not specify the applicable time of pre-nuptial agreement, then the agreement shall be applicable from the time of marriage.

The Decree of the Indonesian Constitutional Court have two legal consequences for mixed marriage and marriage between Indonesian citizen, subject with third party, namely:

1. For the marriage of Indonesian citizen with Indonesian citizen, this situation creates confusion and uncertainty amongst the husband and wife property portion, Notary can also

12 Habib Adjie,"Perjanjian Kawin Pasca Putusan MK" Notarius, Januari-Pebruari 2017, 58. 
find it to be difficult in the implementation of the distribution of the property if the Indonesian Constitutional Court's decree is enforced without the Court decision or extensive promulgation, as this can lead to dispute with third parties who feel that their interest is harmed pursuant to pre-nuptial agreement which is made after the marriage.

2. For mixed marriage between Indonesian citizen and Foreigners, it will create issues in distribution of property of husband and wife and especially as it is related with crosscountry and national interests, then if it disputes occur between husband and wife it will be very difficult for Notary or other officials to separate between husband and wife property from mixed marriage.

The issues of retro-active enforceability and the pre-nuptial agreement shall not harm third party, have actually been anticipated by the Indonesian Constitutional Court because The Indonesian Constitutional Court states in its verdict: "By the time of, prior to, or during marriage, both spouses may jointly agree to draw up a written agreement which is registered with the civil registry officer or public notary, after which time the contents of such agreements will also be applicable to other relevant third parties"; This implies that the prenuptial agreement can be made but it should not harm third parties. However, this clause is quite difficult to execute, because the term of not harming third parties contains a broad sense that is not only applicable for both first party and second party, namely husband and wife but also other parties whose interests are harmed. All of which requires prudence so that the prenuptial agreement shall not be exploited by irresponsible parties to get other benefits. The court decree in the country and also the promulgation in the mass media may be an alternative solution, but this raises consequence that there is a waiting time period before pre-nuptial agreement takes place. After the pre-nuptial agreement is enforced then there are consequences, namely for the couple between Indonesian citizens and Indonesian citizens, there will be a clear separation of property, while for Indonesian citizens who marry Foreigners, then the title to land and buildings that belong to Indonesian citizens will remain Indonesian citizen property.

\section{CONCLUSION}

Pre-nuptial agreement may be made after marriage if the implementation does not harm the third party. Because after the pre-nuptial agreement is made the conjugal property is no longer joint property. The husband and wife property's title shall become their own property title respectively. Thus, Indonesian citizen property shall remain Indonesian citizen property, foreign citizen property shall remain foreign citizen property. Land which is owned by Indonesian citizen may still be owned by Indonesian citizens because there is no joint ownership of property by foreign citizen.

Pre-nuptial agreement which is made after the enactment of Indonesian Constitutional Court Decree still have no legal consequences if it is not followed by the issuance of implementing regulations. this is related to how the pre-nuptial agreement shall not harm third parties, including how to implement the pre-nuptial agreement therefore the third party knows and can undertake an adjustment to the pre-nuptial agreement.

Pre-nuptial agreement which is made after marriage can not be applied like that because it may lead to complex legal consequences if it is implemented. 


\section{RECOMMENDATION}

Marriage Act requires to be adjusted or amended pursuant to the release of provisions of prenuptial agreement which is made after marriage, in particular on how the promulgation and the enforcement of the pre-nuptial agreement therefore will not cause unlawful acts of the prenuptial agreement.

It requires socialization to the Notary and the competent authorities and third parties in making the Pre-Nuptial Agreement to provide an understanding to people who apply for the prenuptial agreement so that there is understanding that the terms of the previous pre-nuptial agreement which is applied before the issuance of the Indonesian Constitutional Court's decree shall remains valid in so far the implementing regulations of the Constitutional Court decree is not yet made.

The government is expected to immediately follow the Indonesian Constitutional Court's decree by immediately issue new legislation or take other instrument to make sure of the legal certainty and no existence of legal uncertainty. Because the people who understand the advantages and benefits of this Indonesian Constitutional Court Decree is bound to take action pursuant to the Decree.

\section{REFERENCES}

Djaja.S.Meliala. (2015). Perkawinan Beda Agama Dan Penghayat Kepercayaan Di Indonesia Pasca Putusan Mahkamah Konstitusi, Bandung: Penerbit Nuansa Aulia.

J. Andy Hartanto.(2017). Hukum Harta Kekayaan Perkawinan "Menurut Burgerlijk Wetboek dan Undang-Undang Perkawinan”, Yogyakarta : Laksbang Pressindo.

J. Prins. (1982). Hukum Perkawinan di Indonesia, Jakarta Timur : Ghalia Indonesia.

J Satrio. (1991). Hukum Harta Perkawinan, Bandung : Citra Aditya Bakti.

K.Wantjik Saleh.(1976). Hukum Perkawinan Indonesia, Jakarta : Ghalia Indonesia.

Marhainis Abdul Hay.(1984).Hukum Perdata Material Jilid I, Jakarta : P.T.Pradnya Paramita.

Martiman Prodjohamidjojo.(2011). Hukum Perkawinan Indonesia, Jakarta, Indonesia :

Legal Center Publisihing.

Moch. Isnaeni. (2016). Hukum Perkawinan Indonesia, Surabaya : Refika Aditama.

Rosnidar Sembiring. (2016). Hukum Keluarga "Harta Benda dalam Perkawinan”, Jakarta : PT

Raja Grafindo Persada.

12 Habib Adjie,"Perjanjian Kawin Pasca Putusan MK" Notarius, Januari-Pebruari 2017, 58. 
Liliana Tedjosaputro : Pre-nuptial Agreement After The Enactment Of Decree .....

R Soetojo Prawirohamidjojo dan Asis Safioedin.(1986).Hukum Orang dan Keluarga, Bandung: Penerbit Alumni.

R Subekti.(2005). Pokok-Pokok Hukum Perdata, Jakarta : Intermasa.

Rachmadi Usman. Aspek-Aspek Hukum Perorangan dan Kekeluargaan di Indonesia. Banjarmasin : Sinar Grafika, 2005.

Ridhwan Indra.(1994). Hukum Perkawinan di Indonesia, Jakarta : Ghalia Indonesia.

RM Suryodiningrat.(1978). Azas-Azas Hukum Perikatan, Bandung : Tarsito.

Soedjono Dirdjosisworo.(1983). Pengantar Ilmu Hukum, Jakarta : RajaGrafindo.

Sri Wahyuni. (2016). Hukum Keluarga dan Dinamika Sosial "Kajian Adat Masyarakat Samin, Maluku, Kalimantan dan Sasak, Yogyakarta: Calpulis.

Sudikno Mertokusumo.(2002). Hukum Acara Perdata Indonesia, Yogyakarta : Liberty.

Sution Usman Adji.(1989). Kawin Lari dan Kawin Antar Agama, Yogyakarta : Liberty.

Wahyuni.(2008). Hukum Perkawinan di Indonesia, Semarang : Penerbit Pustaka Magister Semarang.

(2002). Hukum Perdata I Hukum Keluarga, Semarang : Untag- Semarang.

Wibowo Reksopradoto. (1977). Hukum Perkawinan Nasional Semarang : Itikad Baik.

\section{MAGAZINE}

Abdul Hakim Pradoto Kusumo, "Cermati Bila Menerima Akta Perjanjian Kawin”, Renvoi, 3 Maret 2017

Habib Adjie,"Perjanjian Kawin Pasca Putusan MK" Notarius, Januari-Pebruari 2017. 